\title{
Ayodhya: The Imageability and Perceptions of Cultural Landscapes
}

Professor Rana P.B. Singh ${ }^{+*}$ and Mr Sarvesh Kumar

\section{Abstract}

Most of the visitors (pilgrims in the majority) and the dwellers (mostly Hindus) perform some sorts of rituals at varying degrees and become involved in the religious activities to gain solace or soul healing. Of course, as sidetrack visitors also perform other activities of recreation and side-show. However, these are the marginal activities. It is obviously noted that personality of pilgrims and dwellers in the context of economic, social, cultural, job status, and perspective of life, has a direct effect on the nature of environmental sensitivity to its sacred landscapes and mythologies that support and make them alive. Ongoing rituals, continuous performances of Ramalila in the evening, pilgrimages and auspicious glimpses to the divine images, and associated happenings together make the whole are a part of the sacred environment. These are categorised within the frame of responsive perception, testing Kevin Lynch's scale of imageability represented with the five elements, viz. path, edge, node, district, and landmark. The perceptual survey of dwellers and pilgrims are codified into a composite cognitive map that reflects the generalised images of various behavioural attributes that fit the cultural and natural landscapes of the city; this is similar to other holy cities of north India like Varanasi, Mathura, and Chitrakut.

Keywords: Ayodhya, cognitive map, dwellers, imageability, perception, pilgrims, the Sarayu river, symbols.

\footnotetext{
${ }^{\dagger}$ Ex Professor \& Head, Department of Geography, Institute of Science, Banaras Hindu University, Varanasi, UP 221005, India, Email: ranapbs@gmail.com

* Corresponding Author

' UGC Senior Research Fellow, Department of Geography, Institute of Science, Banaras Hindu University, Varanasi, UP 221005, India, Email: sarvesh1k@gmail.com

(C) 2018 Singh and Kumar. This is an Open Access article distributed under the terms of the Creative Commons Attribution License (http://creativecommons.org/licenses/by/2.0), which permits unrestricted use, distribution, and reproduction in any medium, provided the original work is properly cited.
} 
Introduction: The Imageability and Cultural Perception

The behavioural perspective of human personality is a subjective quality mostly reflected regarding the spatial interaction of man and image formation and its exposition. Every view of spatial vision has a connectedness with the visual landscape, generally perceived and expressed in the form of an image that develops in the mind of settlers, visitors and tourists. The formation of an image is associated with the issues of time, culture, society, education, and mental set-up, that is, altogether it portrays the overall personality of people and place. The first idea of cognitive mapping has been initiated by Trowbridge (1913) who has emphasised the role of orientation. His ideas were further elaborated by Tolman (1932) with addition of the concept of spatial behaviour and related cognitions. The first pioneering work has been established by an American architect Kevin Lynch (1918-1984) by his classic, The Image of the City (1960) in which he has explained the imageability and legibility through the cognitive behaviour of visitors and tourists. After a quarter of a century after Kevin Lynch's work, his contributions are further elaborated in an international seminar and its proceedings, 'Reconsidering the Image of the City' (Rodwin and Hollister, 1984). In the field of environmental psychology and behavioural geography the study of cognition and spatial behaviour received special attention, including taking tourists as samples (cf. Golledge, 1987; for recent reviews see Gobster, et al., 2003, and Eisler, et al., 2003).

The key purpose of this research is to examine as to how the visitors perceive and imagine Ayodhya. Is it simply a cultural landscape or birthplace of Lord Rama or both. The research is built on the frame of responsive perception via testing of Kevin Lynch's scale of imageability represented with the five elements - path, edge, node, district, and landmark. The perceptual survey of the dwellers and the pilgrims are codified into a composite cognitive map that reflects the generalised images of various behavioural attributes that fit into the cultural and natural landscapes of the city. In his assessment, Lynch (1984) provoked that his original theoretical construct is proved valid by the later contributors that culture and familiarity much modify images. I. He realised that map drawing is a misleading index for most of the people. He also felt that exposition of satisfaction and identification emotionally certainly gives a distorted viewpoint. Nevertheless, in a culturally rich and traditionally variant society like India, the modified version of Lynch has worked satisfactorily. Lynch's advocacy that his approach and study to be taken as a hammer to hit the policy planning in making the city more liveable for the dwellers has not yet taken due consideration. However, cognitive data of tourists indicates its validity in promoting better structure of tourism.

In India, the imagery theory of Lynch was introduced and tested by Singh and Singh (1980); this study is further elaborated on the line of imagery questionnaire used for interviewing tourists and visitors to Banaras (Singh 1988). He further tested the same frame in his follow up study taking fifty respondents from Deoria town (cf. Singh and Shahi 1988). It has been observed that personality of tourists/visitors in the context of economic, social, cultural, job status, and perspective of life, has a direct effect on the nature of environmental sensitivity to its cultural landscapes and heritagescapes that result to form cognitive maps.

The research begins with a geographical description of Ayodhya. This is followed by discussions of how Ayodhya is perceived within the collective imaginations of the visitors and the locals. The concluding remarks are outlined in the final section.

\section{Ayodhya: The Geographical Personality}

Ayodhya, being one of the most sacred places is known as the legendary capital of Rama; and nowadays one of the most important places of pilgrimage in India with special reference to its sacred cultural landscapes. Ayodhya, situated on the right bank of Ghaghara River (Sarayu) 
(Fig.1), is primarily an ancient tirtha (riverfront sacredscape) and salvific place that records settlement continuity since at least ca 800 BCE. Ayodhya is assumed to be the birthplace of Lord Rama, a mythological seventh incarnation of the God Vishnu, a major deity of Vaishnavite group who established the order of 'continuity and existence of organism'. Ayodhya was one of the famous cities and the first capital of the powerful Koshala among the 16 Mahajanapadas of ancient India (Kumar and Singh 2013: 7).

The waterfront city of Ayodhya means that "which cannot be subdued by war" counted among the seven most sacred and abodes for salvation (Puris), and place of pilgrimage of the India, is situated on 26 $46^{\prime}$ north to 26 ㄴ $49^{\prime}$ north latitude and 82 10' east to 82 $16^{\prime}$ east longitude in the Faizabad district (state of Uttar Pradesh) on the right bank of the river Sarayu (Ghaghara) (Figure 1).
The riverfront banks of the Sarayu at Ayodhya consists of a number of bathing places (ghats), and are counted as sacred places for Hindu adherents. Some of them are Pakka, having flights of stone steps leading down to the river, while others are called Kaccha, just mud bank. Svaragadvara Ghat is the most famous ghat, where the pilgrims come for pilgrimage and holy dip and perform other rituals. Other important ghats are situated on the eastern and the western side of the bank. Every ghat possesses individual historical, mythological, religious folk tales and spiritual importance. The riverfront also consists of sacred places like monastic temples, ashrams, and chhavani (encampment of monks). Every year on the special occasion of Parikrama, pilgrims perform the first ritual of sacred bathing (snana), followed by pilgrimage (yatra) to the Panchakroshi and Chaudahakroshi yatras from various ghats of the Sarayu river.

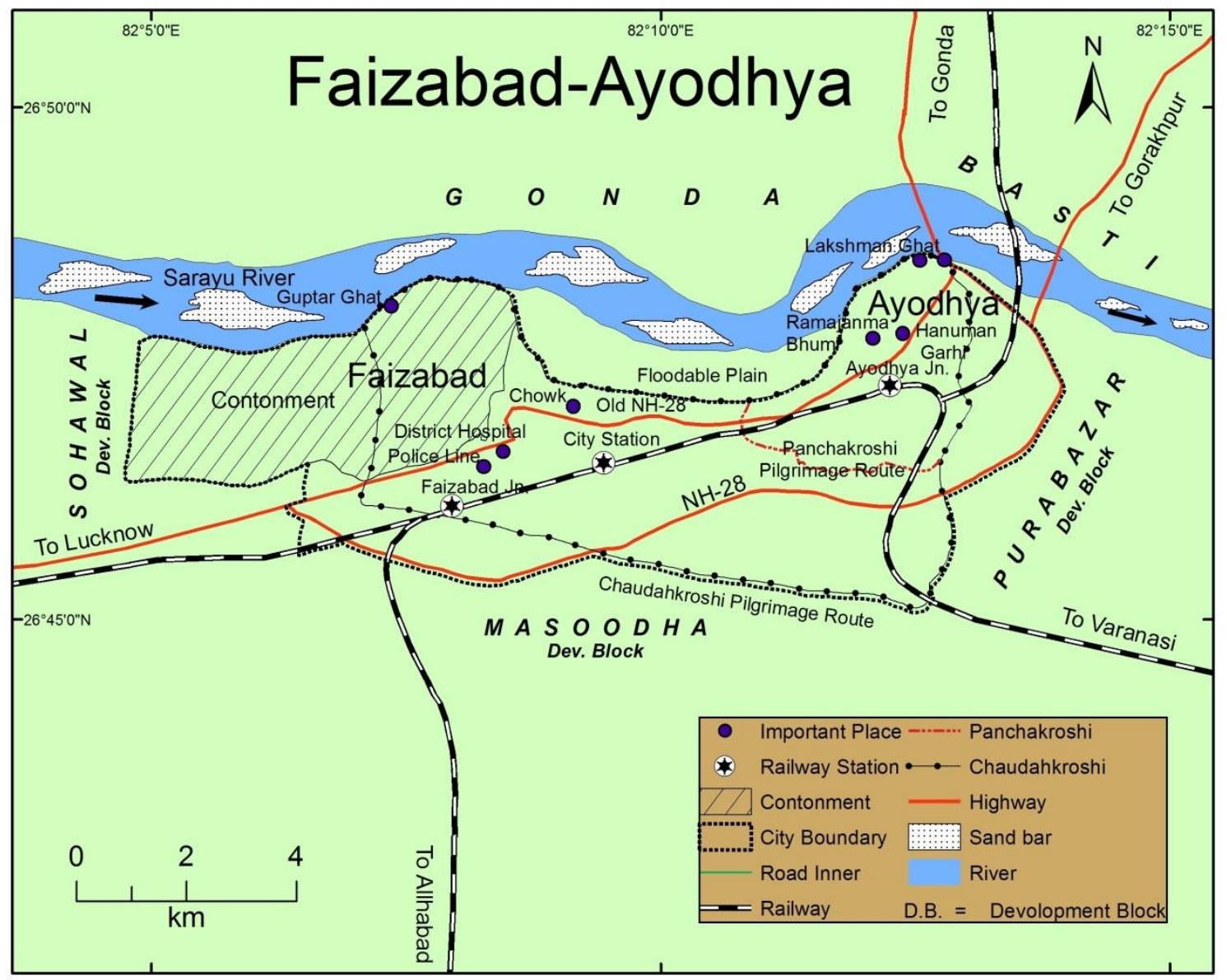

Figure 1: Location of Ayodhya-Faizabad

\section{Ayodhya: First/Overall Impression}

At the first impression, the city is most frequently accepted as one of the most sacred places for Hindus. According to both respondent dwellers and pilgrims, Ayodhya is the birthplace of Rama and also Hindu known 
as the city of Ramajanmabhumi (Table 1). The city consists of a great mass of sacredscapes (sacred spots, sites and artefacts), the majority of which are linked to the riverfront. Such unique places have become essential to the lives of devout Hindus because of the community use or symbolism associated with their faith in the deep attachment. The overall first impression of the dwellers and pilgrims is associated with the religious notion (sacred place of the pilgrimages) together with serenescenic lofty ghats making the riverfront along the Sarayu River, and the conception of sacredness (Rana and Singh 2011: 182).

The walk along the ghats, followed steps, sound of the temple bells, smell of the flowers, the style mood and dealing of the priests there, a continuous chain of people for taking holy dip, gurgle of the river and murmur of recitation of sacred mantras by devotees after taking holy dip, the rituals at the ghats and in nearby temples, devotees' facial expression of faith altogether make the riverfront landscape an unique scene in the 'world of faith and rituals' (cf. Kumar and Singh 2017). In other words, this whole arena may be called a distinct faithscape, which has only to be understood with personal experience and faith because this is not only scenic or traditional way, but also a way for making themselves a connected to the spirit of ultimate reality.

\section{Table 1-Ayodhya - Perceptual Responses: First Impression}

\begin{tabular}{lcccc} 
First Impression & Dwellers & Pilgrims & All Respondents & Percentage \\
\hline Religious/ pilgrimage city & 8 & 2 & 10 & 11.7 \\
\hline City of ancient temples & 3 & - & 3 & 3.6 \\
\hline City of Ramajanmabhumi & 48 & 12 & 60 & 70.5 \\
\hline City of riverfront ghats & 3 & - & 3 & 3.5 \\
\hline Salvific city & 5 & 1 & 6 & 7.1 \\
\hline Dirty \& crowded city & 2 & - & 2 & 2.3 \\
\hline Not answered & 1 & - & 1 & 1.2 \\
\hline \multicolumn{1}{c}{ Total } & $\mathbf{7 0}$ & $\mathbf{1 5}$ & $\mathbf{8 5}$ & $\mathbf{1 0 0 . 0}$
\end{tabular}

Source: Personal Survey and Collation of Data

\section{Symbolic Meaning of Ayodhya}

Ayodhya is full of symbols and its various meanings like other sacred places in India, for example, 'the city situated on a boat of Manu', 'the city of temples', 'the city of salvation, etc. On the basis of symbols, surveys conducted that shows that ca 73 per cent of dwellers and pilgrims of total respondents expressed this place as 'the city of Rama' and only 12 per cent expressed this place as "the city of Hanuman" (Table 2). As per common perception Hanuman is inseparable from Lord Rama, either in imagery or mythic story. That is how 85 per cent respondents fall under the joint category of these two symbolic meaning.

Water is a dominant feature in many environments and cultural heritage; in India, water has special importance historically and more specifically in Hindu thought water had been given prominence as ethereal liquid energy (prana shakti) which can clean all sorts of sins and provides a new life. On this line of thought the Sarayu river, in a regional context, is archetypically mythologised as 'motherly river' ('Sarayu $M a^{\prime}$ '), a cradle of Indian culture and civilisation together with the Ganga river, as a symbol of prosperity and purity. 
Table 2- Ayodhya - Perceptual Responses: Symbolic Meaning

\begin{tabular}{lcccc} 
Symbolic meaning & Dwellers & Pilgrims & All Respondents & Percentage \\
\hline City of Rama & 47 & 15 & 62 & 72.9 \\
\hline City of Hanuman & 11 & - & 11 & 12.9 \\
\hline Symbol of Hindu religion & 6 & - & 6 & 7.0 \\
\hline City of Sarayu River & 3 & - & 3 & 3.5 \\
\hline City of Tirthankaras & 2 & - & 2 & 2.4 \\
\hline City of Hazrat Noah & 1 & - & 1 & 1.1 \\
\hline \multicolumn{1}{c}{ Total } & $\mathbf{7 0}$ & $\mathbf{1 5}$ & $\mathbf{8 5}$ & $\mathbf{1 0 0 . 0}$
\end{tabular}

Source: Personal Survey and Collation of Data

\section{Soundscape and Smellscape}

Among the non-visual senses related to environmental aesthetics smell and sound are the most distinct ones. Since both are related to space, time and human concern they ultimately form distinct places, that is, smellscape and soundscape. These two spatially-ordered places especially the obnoxious smell of sewage disposal spots and the unwanted sound converging to form 'noisescape' are the major concerns of sensibility and reaction as clearly marked by the tourists. An aspect of sound and smell also play a role in stability, comfortability and resistance of devout Hindus. Sound and smell phenomena are surveyed together and categorised into five and four aspects, respectively (cf. Table 3).

Table 3- Ayodhya - Perceptual Responses: Soundscape and Smellscape

\begin{tabular}{lcccc}
\multicolumn{1}{c}{ A. Aspects of Sound } & Dwellers & Pilgrims & All Respondents & Percentage \\
\hline Bells' sounds \& mantras' chant & 23 & 8 & 31 & 36.4 \\
\hline Temple and street music & 16 & 3 & 19 & 22.3 \\
\hline Traffic noise & 15 & 1 & 16 & 18.8 \\
\hline Gurgle of the river (Sarayu) & 11 & 2 & 13 & 15.2 \\
\hline Chirping of birds & 5 & 1 & 6 & 7.0 \\
\hline Total & $\mathbf{7 0}$ & $\mathbf{1 5}$ & $\mathbf{8 5}$ & $\mathbf{1 0 0 . 0}$ \\
\hline B. Aspects of Smell & & & & \\
\hline Fragrance of Flowers and Mala & 26 & 6 & 32 & 37.6 \\
\hline Fragrance of Dhup, Havan and & 27 & 4 & 31 & 36.4 \\
Agarbatti & & & & \\
\hline Obnoxious smell of garbage & 10 & 3 & 13 & 15.2 \\
\hline Smell of urine/sewer & $\mathbf{7}$ & $\mathbf{2}$ & 9 & 10.5 \\
\hline Total & $\mathbf{7 0}$ & $\mathbf{1 5}$ & $\mathbf{8 5}$ & $\mathbf{1 0 0 . 0}$ \\
\hline Source: Personal Survey and Coll & & &
\end{tabular}

Source: Personal Survey and Collation of Data

Like other holy cities, Ayodhya too is famous for ringing morning bells, chanting of sacred verses and devotional songs devoted to different deities, quite common in the shrines along all the old streets (recording around 70 per cent). Sometimes these sounds attract, but when it becomes noise, it also distracts. The rippling and gurgling of the river (Sarayu), temple and street music and chirping of birds are liked by the dwellers and the pilgrims, mostly because of their religious notions. It is obvious, that more than 70 per cent of the dwellers and pilgrims attracted by the fragrance of dhup (incense), havan and agarbati (fire ritual items) and fragrance of the flowers and mala (garlands) (Table 3). Respondents also reacted to the obnoxious smell of garbage and smell of urine (around 25 per cent). There is a big shortage of toilet facilities, especially close to the important sacred sites, this result in using open spaces for this purpose.

The results of a study of Banaras are similar to that of Ayodhya; it is noted that 'domestic pilgrims and visitors [tourists] are less 
conscious, resulting into lack of any dominant trend. Noise in the streets, shouting among the localities and high pitch music always distract both kinds of people - dwellers and the devout visitors' (Rana and Singh 2011: 187). The soundscape as expressed in the sonic environment created by pilgrims to awaken the divine being and marking their appearance in their presence be seen in a poem (Singh 2002: 173):

The $t a \dot{n}-\tan$, tin- tin, i.. n.. g

The sound from temple-tower,

Giving message in the morning hour,

Divine Beings are ready to bless,

This is a call for glimpse and wish.

Offering different food and flowers and related ritual items at the shrines, particularly at the most commonly visited temples, inherently make a smellscape (Singh 2002: 172):

The sweetly smell of offered foods,

The smoky smell of incense-goods

The smell of wet clothes and the colour,
Resulting in smellscape every hour (Rana and Singh 2011: 188).

\section{Distinctiveness of Elements vis-à-vis Identify and Remembrance}

Every place or site possesses its own 'generality' and 'distinctiveness' in comparison to other similar places that records the similar historical-cultural processes of evolution, growth, sprawl, and maintenance of its existence. These characteristics directly influence the perceptual responses of the people. In the span of time, the scenes and incidents that had recorded wide propaganda and caught the mind of the people helped in generating acceptability of distinctiveness. In case of Ayodhya, the demolition of Babri mosque on the 6th of December 1992, has still has been the prominent image about Ayodhya, recording above sixty per cent of responses. As the most commonly followed up visited sites, Hanumangarhi and the riverfront Sarayu are the other important elements. The uninterrupted performances (anavarat) of Ramalila since last two decades have also recorded special attention to identifying the distinctiveness of the city (see Table 4).

Table 4-Ayodhya - Perceptual Responses: Distinctiveness of Elements

\begin{tabular}{lcccc} 
Distinctiveness of Elements & Dwellers & Pilgrims & All Respondents & Percentage \\
\hline $\begin{array}{l}\text { Ramajanmabhumi- Babri mosque } \\
\text { contestation }\end{array}$ & 37 & 15 & 52 & 61.1 \\
\hline Hanumangarhi & 15 & - & 15 & 17.6 \\
\hline Sarayu River & 10 & - & 10 & 11.7 \\
\hline Kanak Bhavan & 5 & - & 5 & 5.8 \\
\hline Anvarat (continuous) Ramalila & 3 & - & 3 & 3.5 \\
\hline Total & $\mathbf{7 0}$ & $\mathbf{1 5}$ & $\mathbf{8 5}$ & $\mathbf{1 0 0 . 0}$
\end{tabular}

Source: Personal Survey and Collation of Data

Sacredness and Symbol Identity of Ayodhya

If the idea of architecture is to be used as "planned human construction", the designing of a city is essentially a specific transformation of human creativity, often interpreted in the context of signs and symbols and the invisible meaning preserved there. The presentation of wholeness - the representation of cosmos leads to form a sacred geometry referring to the spiritual and archetypal dimensions of pattern/relationship, order/sequences and temporality/changes. This frame forms harmonic and sensual bondage between man and his habitat, the city (Singh 1994: 190). In the Oriental World, "sacred schemata and meaning are most important ones, and cities in those cultures can be understood only in such terms" (Rapoport 1990: 28). Denny (1991: ix) also described the sacred city in terms of cosmology, "A city can be sacralised by laying out of its plan according to the cosmology of the region, thus, uniting realm and ruler in a 
pattern of sacred kingship." Among thousands of temples and shrines in Ayodhya, seven have recorded special attention by the respondents (Table 5).

All these sites possessed mythological and historical legends describing the power of sacrality and its associated salvific power for fulfilling the wishes, healing and soul healing. With reference to different attributes that records the maximum intensity of attraction and images is the Ramajanmabhumi, followed by the palace-cum-temple of Kanak Bhavan, which is believed was presented as a gift to Sita, wife of Lord Rama, by her mother-in-law.

\section{Table 5- Ayodhya - Perceptual Responses: Sacredness and Symbolic Identity}

\begin{tabular}{lc}
\hline Identity of Sacred Place & Dwellers \\
\hline Ramajanmabhumi & 28 \\
\hline Kanak Bhavan & 20 \\
\hline Hanumangarhi & 10 \\
\hline Sarayu River & 5 \\
\hline Nageshvarnath Temple & 3 \\
\hline Devkali Temple & 2 \\
\hline Jain Temples & 2 \\
\hline Total & $\mathbf{7 0}$ \\
Source: Personal Survey and Collation of Data \\
$\begin{array}{l}\text { Idiosyncratic Scene of Ayodhya that Makes it a } \\
\text { Unique City in India }\end{array}$
\end{tabular}

Idiosyncratic scene refers to unusual and odd images and perception of the landscape that expresses eccentricity or peculiarity or sometimes 'symbolic expression', mostly funny but popularly shared both by the visitors and dwellers. Every site or landscape is manifested with an idiosyncratic map that generated through the cultural notions and maintained by the folk tales and legends. The idiosyncratic

Pilgrims

All Respondents

Percentage

\begin{tabular}{ccc}
12 & 40 & 47.0 \\
3 & 23 & 27.0 \\
- & 10 & 11.7 \\
- & 5 & 5.8 \\
- & 3 & 3.5 \\
- & 2 & 2.3 \\
- & 2 & 2.3 \\
\hline 15 & 85 & 100.0
\end{tabular}

map satisfies everyday needs and makes the mind to accept the unwanted situation. In a way, this notion also refers to the 'vague' perception and 'distinctiveness' of the city. Most commonly distinctiveness of Ayodhya is expressed as the 'city of temples' and 'sadhus'. This perception is echoed by about half of the responses (see, Table 6). Being a city of 'monkeys' and 'birthplace of Rama' are the other responses, followed by 'city of caste temples'.

\section{Table 6-Ayodhya - Perceptual Responses: Distinctiveness that Marks Uniqueness.}

\begin{tabular}{lcccc}
\hline Distinctiveness mark, City of & Dwellers & Pilgrims & All respondents & Percentage \\
\hline - temples & 16 & 5 & 21 & 24.7 \\
\hline - Sadhus & 19 & 1 & 20 & 23.5 \\
\hline - Monkeys & 10 & 3 & 13 & 15.2 \\
\hline - birth place of Rama & 8 & 5 & 13 & 15.2 \\
\hline - Festivals/ Mela & 7 & - & 7 & 8.2 \\
\hline - Kunds (water pools) & 6 & - & 6 & 7.0 \\
\hline - Caste Temple & 2 & - & 2 & 2.3 \\
\hline - Anavarat (continuous) Ramalila & 2 & - & 2 & 2.3 \\
\hline - No Answer & - & 1 & 1 & 1.1 \\
\hline Total & $\mathbf{7 0}$ & $\mathbf{1 5}$ & $\mathbf{8 5}$ & $\mathbf{1 0 0 . 0}$
\end{tabular}

Source: Personal Survey and Collation of Data

Ayodhya: Respondents' Perceptual Sketches and Pilgrims' Faithscapic Map

Like other riverfront sacred cities, like Varanasi, the march towards riverfront ghats, followed sacred path (pāvan path) to temples, soundscapes and smellscapes surrounding the temples, the style mood and dealing of the priests there, a continuous chain of people for taking holy dip and visitation to temples, gurgle of the river and murmur of recitation of sacred 
mantras by devotees after taking holy dip, the rituals at the ghats and in nearby temples, devotees' facial expression of faith altogether make the city and ghats an unique scene in the 'world of faith and rituals', in other words, a distinct faithscape which has only to be understood with a personal experience and faith because this is not only scenic or traditional way but also a way for making themselves a part of divine association with an aim to understand the ultimate reality through bridging between awakened mind of human being and sublime infinity of the divine (cf. Singh 1988: 12). Both the physical and cultural elements and the human processes and performances make the faithscape distinct, especially the riverfront ghats, and disparate from the nearby localities (see, Figure 2).

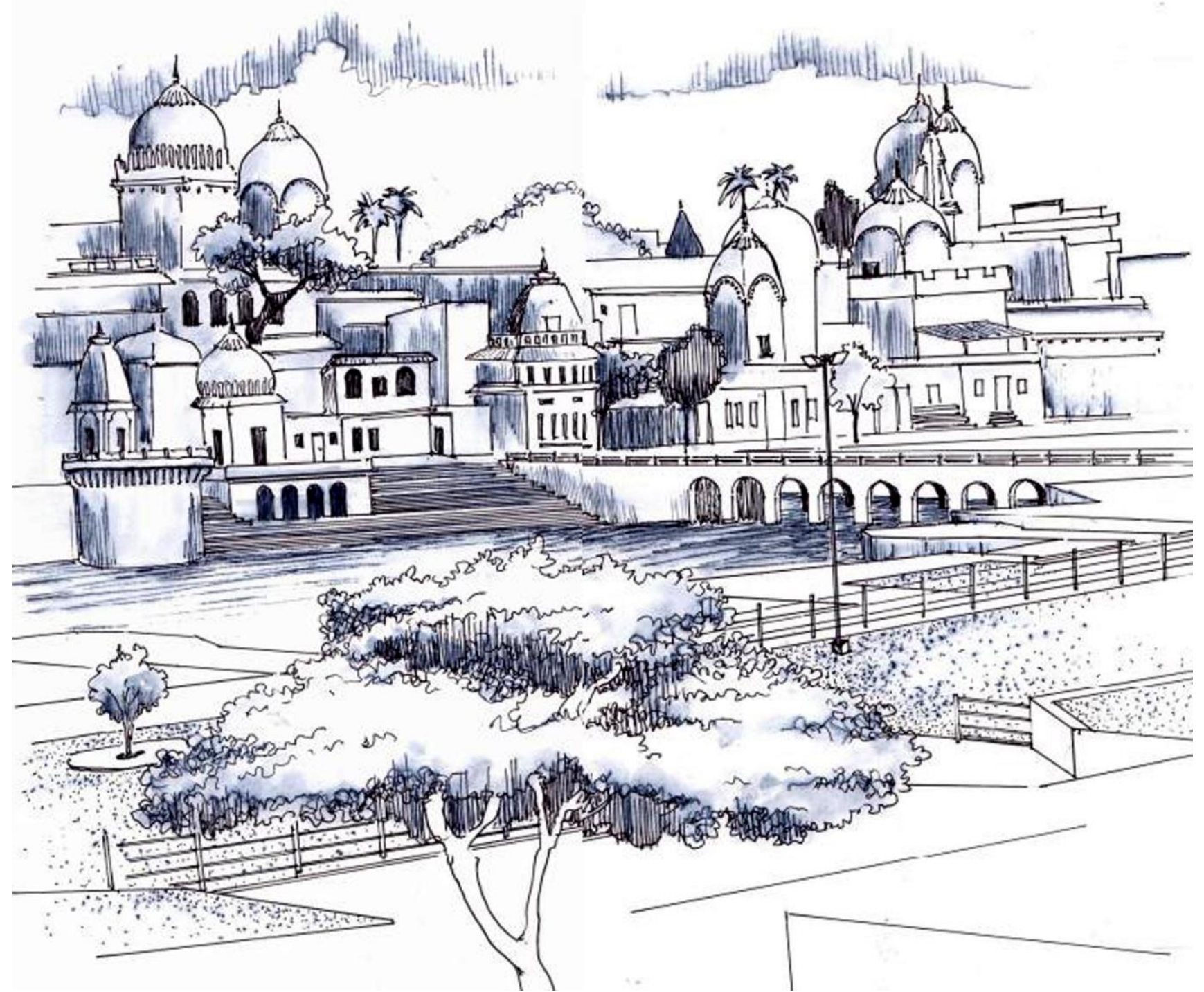

Figure 2- A Scene of Sarayu's ghats: Ram Ki Paidi to Svargadvar

Courtesy: Krishna Kumar 


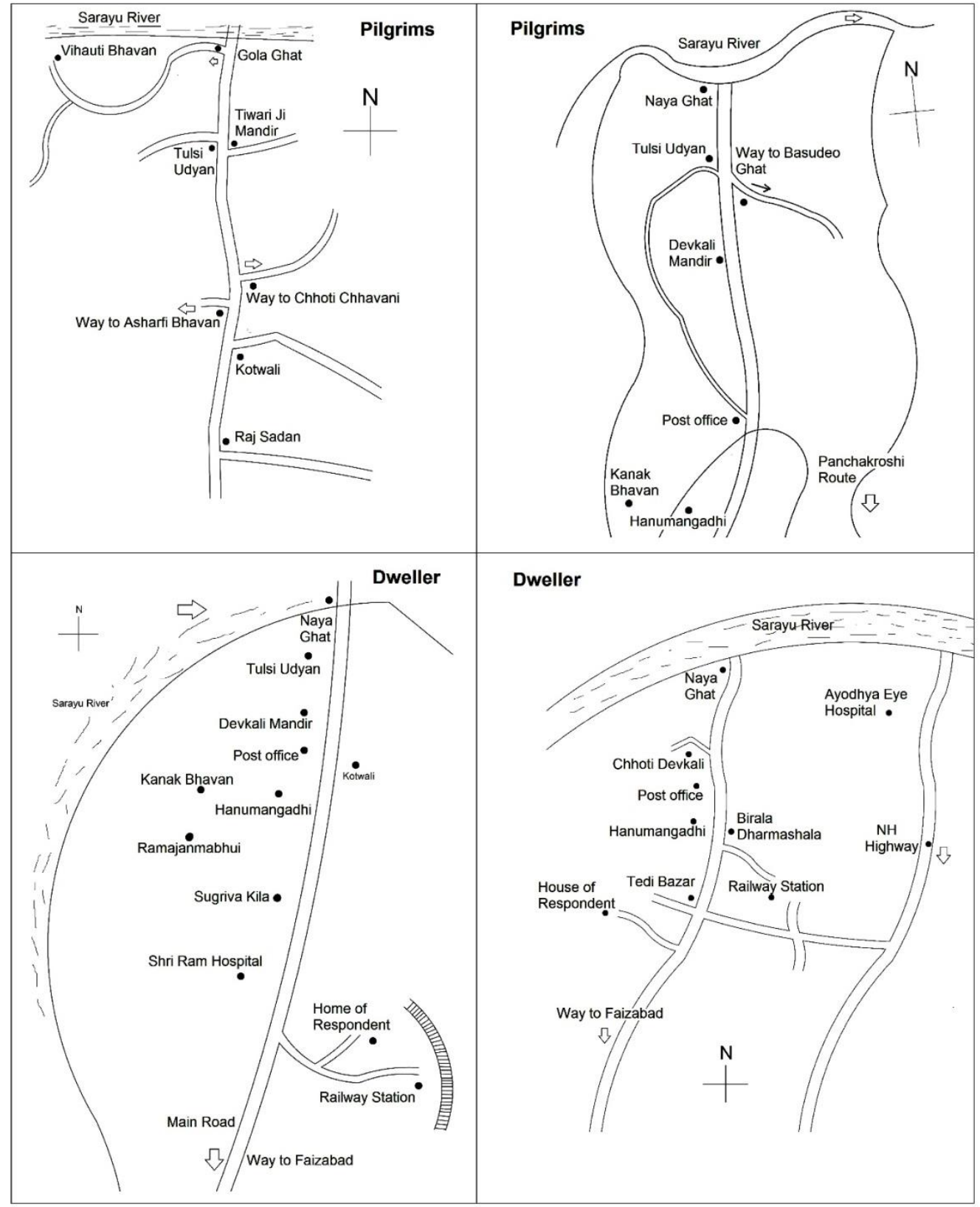

Figure 3- Ayodhya: Respondents' Perceptual Sketches, Re-drawn (A, B, C, D)

The visitors' orientation towards the environmentally clean and the environment of recognition of the city when compared to its residents gained $t$ much importance. They considered that the "dwellers are proud of their city" being the birthplace of Lord Rama, "people are trying to prevent and preserve the life of Ayodhya", "many people come here for religious pursuit because they regard it as one of the holiest cities of India", described in Puranic literature as one among the seven cities of granting salvation (moksha-dayini), etc. However, at the same time, it was also observed that people made the city more commercial, polluted, and haphazard than its sacred-holy character. Also, lack of civil sense, community-based institution to make the city contestation, altogether make the image of the city ugly and confused. The level and quality of images are so diverse and complex that it is almost difficult to give a final shape to the imagery landscape (see Fig. 3). But in spite of several contrasts, there also exist many similarities which help in making a generalised cognitive' map of the city (see, Figure 5).

In a popularly sold contemporary visitors' cognitive map of Faizabad-Ayodhya, the part of Ayodhya was not given prominence; of course, a few of the important temples are mentioned along with some other sacred places (Figure 4). A metaphorical notation written at the central 
part of bottom says, "if I write Sri Rama, conceive it as Ayodhya; and if I say - perceive it as Faizabad". This is a vague and naïve representation of the sacred city. It is obvious from a perceptual survey that the pilgrims and devout Hindus perceive Ayodhya in the frame of the psycho-faith system rather than spaceoriented location; they perceive it as "the land of Rama's life incidences". In this map, the landmarks (in Lynch's terminology) and the attached commonly visual scenes are plotted, including the distinct feature of the two monkeys that easily indicate the dominance of their population. Similarly, the indication of the Pandas (priests) and their act of grabbing visitors for rituals is sketched out too. At one place, it mentions: "It's not a city you see, it's a city you feel...because it is our ancient Ayodhya Nagari". In case of Varanasi, Mathura, and Chitrakut such pilgrims' cognitive maps are more legible, distinct and full of sacred codifications (Singh 1988, 2009: 209-242, Singh and Dubey 1988). Surprisingly, the Saryu river, Ramajanmabhumi and temple of Nageshvaranath are missing (Figure 4).

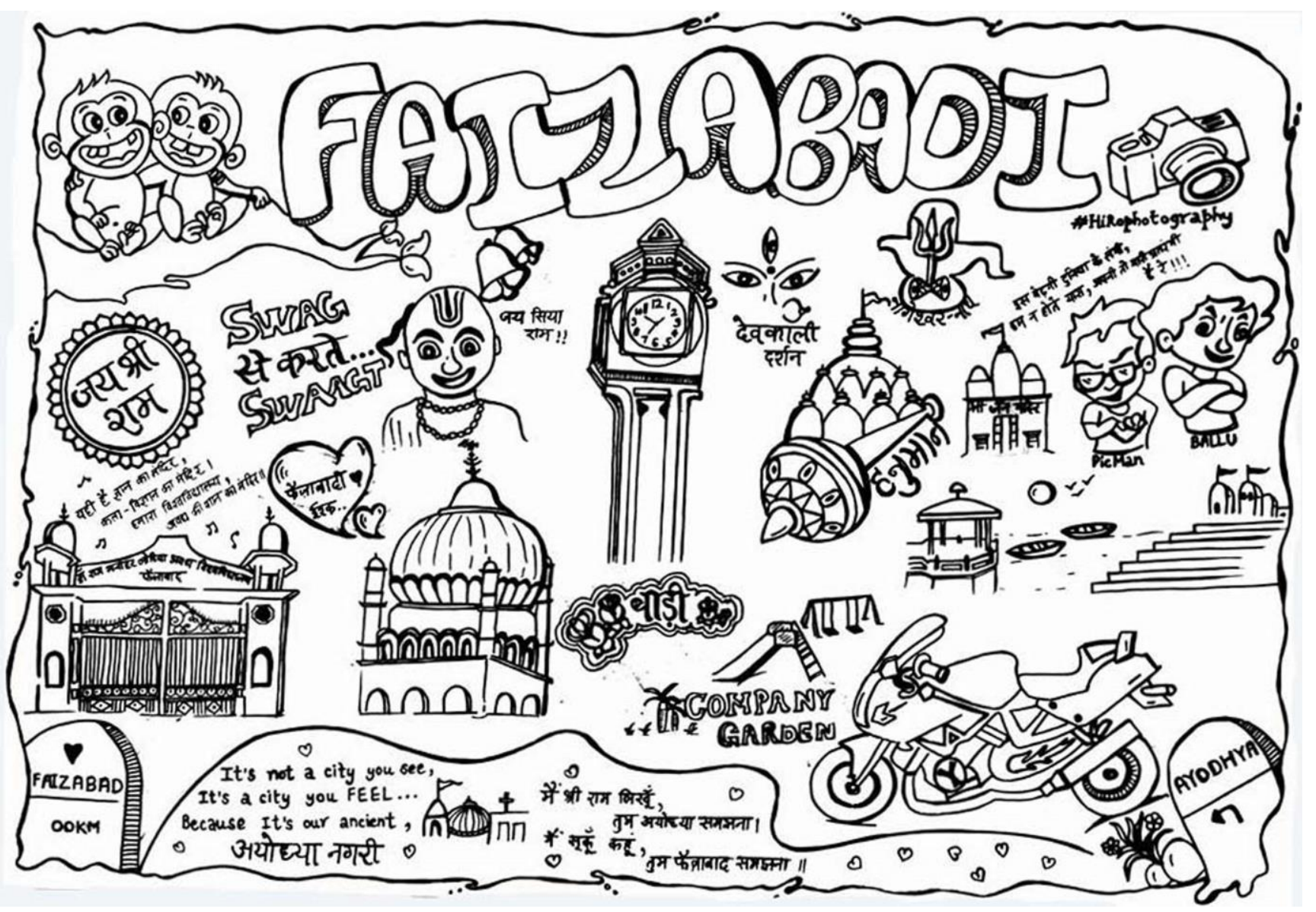

Figure 4- Faizabad-Ayodhya: A Visitor's Cognitive Map

In terms of cartography such maps lack physical reality, but they express intimate experiences of people or of things which are difficult to make public (cf. Carmona et al. 2010), but they are not impossible to express; moreover, they may be personal and deeply felt (Tuan 1977: 147). Only with intimate sensing and concentration, one can support this idea.

\section{Ayodhya: Elements of Cultural and Historic Urban Landscapes}

In the area of environmental psychology and landscape cognition, five themes are considered basic in the study of urban images (Singh 1988: 12), viz. definition and scope, explicitness of their formulation, function of urban images, relationship of the observer to the reality, and immediate and long-term prospects (Rodwin and Hollister 1984: 3-4). One 
might find that all these themes are closely connected. In the context of pilgrimage centres in India, the idea of "image" may be defined as the state and level of faith and perception developed in the span of time. Since such centres are considered as the abode of divinities, its image becomes a dynamic-stored knowledge about which the person is always, aware and wish to visit. The issue of formulation refers to historical processes and social context along with the variation and distinction in different cultural groups. Man wants to make his will a reality; in this context "image" functions as a channel between 'liminality' and 'reaggregation' through changes and memory. The mentally stored knowledge and physically existent aspects might have many similarities and contrasts. Therefore the interpretation of relationship has an important role. Finally, the study of the image in the light of change and future scope will highlight its prospect, especially with reference to people-participation and design making in heritage city like Ayodhya.

The first idea to test the visual quality of city has been initiated by Kevin Lynch (1962), who analysed various levels of legibility and imageability. On the basis of his detailed observation he has prepared hierarchy of five classes of landscape imagery: Path - the channel of movement, Edge - the linear element binding the space or signifying it as a barrier to movement, Node - focal point or destination of attraction, District - part displaying a high degree of homogeneity, and Landmark - the points (e. g., specific buildings) making a sense of reference. Like other holy cities of the world, these attributes are clearly marked with the various level of identity, over the map of Ayodhya (Figure 5). First of all the responses are identified and categorised on the five elements of Kevin Lynch's scale, emphasising the objects and attributed mentioned by the respondents (Table 7).
Following Lynch, many attempts have been made to study city images (cf. Golledge 1987: 148-150), but only a few attempt has been made in India, where preliminary survey of tourists' cognitive maps of Varanasi and Deoria have been discussed in Lynch's scale of five elements (e.g. Rana and Singh 2011, Singh and Shahi 1988, Singh and Singh 1980). However, the historical-cultural background and the puranic sources have not been taken into consideration. Here, an attempt has been made to extend the study in the light of Hindu codification of the city's personality as narrated in ancient literature and also as familiarly exposed by the dwellers or visitors/pilgrims. For this purpose, historical, comparative, faithscapic and phenomenological approaches are applied.

While taking into an appraisal of the earlier studies in case of Indian cities, here, the concept of imageability to Ayodhya has been used in a simple and easy manner what is proposed by Lynch (1960: 141-142). The imageability refers to that 'quality in a physical object which gives it a high probability of evoking a strong image in any given observer'. ... "It might also be called legibility, of perhaps visibility in a heightened sense, where objects are not only able to be seen but are presented sharply and intensely to the senses" (Lynch, 1960: 9-10). All his "questions" were taken into consideration 'with modification in befitting into the cultural landscapes of Ayodhya and its nearby environ. Additionally, the respondents were asked to locate familiarity (cf. Halperin 1988: 5) aspects of their sketch, and later, on the map supplied to them. This lengthy interview took about two hours, and the data received were collated and transferred manually taking into adjustment and measuring differences between the actual and perceived location of the object. 


\section{Table 7- Perceptual Responses: Elements of Cultural and Historic Urban Landscapes}

Elements

Path

Landmark

Edge

District
1. Ayodhya-Faizabad Road

2. Hanumangarhi-Kanak Bhavan Rd

3. Post office-Asharfi Bhavan Road

4. Pramod Van- Chhoti Chavani Rd

5. Tedi Bazar- Mani Parvat Road Not answered, NA

Total

1. Hanumangarhi

2. Shri Ram Hospital

3. Naya Ghat

4. Post Office

5. Raj Sadan

6. Sabji Mandi

7. Tedi Bazar

Not answered, NA

Total

1. North (River)

2. East (Bypass road)

3. West (Lucknow road)

4. South ( Gorakhpur NH)

Not answered, NA

Total

1. Ramajanmabhumi

2. Hanumangarhi

3. Kanak Bhavan

4. Nageshvarnath Temple

5. Svaragadvara

6. Mani Parvat

7. Bashudeo Ghat

8. Devkali Temple

9. Chhoti Chavani temple

10. Adinath Temple Raiganj

Not answered, NA

Total

1. Ramkot

2. Svaragadvara

3. Ram Ghat

4. Raiganj

5. Mani Parvat

Not answered, NA

Total

Dwellers

Pilgrims

\begin{tabular}{cccc}
32 & 3 & 35 & 41.2 \\
24 & 7 & 31 & 36.5 \\
9 & - & 9 & 10.6 \\
3 & - & 3 & 3.5 \\
2 & - & 2 & 2.3 \\
- & 5 & 5 & 5.9 \\
\hline 70 & $\mathbf{1 5}$ & $\mathbf{8 5}$ & $\mathbf{1 0 0 . 0}$
\end{tabular}

23

14

6

29

34.2

7

5

5

4

4

$-9$

70

26

16

11

11

6

70

23

17

9

9

5

3

3

2

1

1

\begin{tabular}{cccc}
1 & - & 1 & 1.2 \\
\hline- & - & - & - \\
\hline 70 & 15 & 85 & 100.0 \\
31 & 12 & 43 & 50.7 \\
20 & 1 & 21 & 24.7 \\
\hline 9 & - & 9 & 10.6 \\
\hline 6 & 1 & 7 & 8.2 \\
\hline 2 & - & 2 & 2.3 \\
2 & 1 & 3 & 3.5 \\
\hline 70 & 15 & 85 & 100.0
\end{tabular}

70

31

20

\begin{tabular}{cccc}
1 & - & 1 & 1.2 \\
- & - & - & - \\
\hline 70 & $\mathbf{1 5}$ & $\mathbf{8 5}$ & $\mathbf{1 0 0 . 0}$ \\
31 & 12 & 43 & 50.7 \\
\hline 20 & 1 & 21 & 24.7 \\
9 & - & 9 & 10.6 \\
6 & 1 & 7 & 8.2 \\
\hline 2 & - & 2 & 2.3 \\
2 & 1 & 3 & 3.5 \\
\hline 70 & $\mathbf{1 5}$ & $\mathbf{8 5}$ & $\mathbf{1 0 0 . 0}$
\end{tabular}

9

2

2

70

$\begin{array}{cccc}\mathbf{7 0} & \mathbf{1 5} & \mathbf{8 5} & \mathbf{1 0 0 . 0} \\ 26 & 4 & 30 & 35.4\end{array}$

- 14

14

14

16.5

$13 \quad 15.3$

$\begin{array}{ll}7 & 8.2\end{array}$

$5 \quad 5.9$

4

4

4.7

4.7

10.5

10.5

$16-16 \quad 18.8$

$11-\quad 11 \quad 12.9$

$\begin{array}{cccc}1 & - & 11 & 12.9 \\ 6 & 11 & 17 & 20.0\end{array}$

$\begin{array}{cccc}6 & 11 & 17 & 20.0 \\ 70 & 15 & 85 & 100.0 \\ 23 & 9 & 32 & 37.7\end{array}$

$\begin{array}{llll}4 & 21 & 24.8 \\ 1 & 10 & 11.7\end{array}$

$\begin{array}{ccc}1 & 10 & 11.7 \\ 1 & 8 & 9.4\end{array}$

$\begin{array}{llll}7 & 1 & 8 & 9.4 \\ 5 & - & 5 & 5.9 \\ 3 & - & 3 & 3.5\end{array}$

$\begin{array}{llll}- & 2 & 2.3\end{array}$

$\begin{array}{lll}- & 2 & 2.3 \\ - & 2 & 2.3\end{array}$

$\begin{array}{lll}- & 2 & 2.3 \\ - & 1 & 1.2 \\ - & 1 & 1.2\end{array}$

Source: Personal Survey and Collation of Data 
Ayodhya: Spatial Representations and the Resultant Cognitive Map

The data has been further categorised and arranged taking into account the frequency of responses into four groups (see Table 8). The composition of all the frequency of responses is plotted on the given map showing the ascending order of their values that which resulted in the emergence of the cognitive map (Figure 5).

A legible mental map (example, Figure 5) gives people an important sense of emotional attachment and security, that is how it serves as the framework for communication and conceptual organisation, and heightens the depth and intensity of everyday human experience. The city itself is thus, a powerful symbol of a complex society, argues Lynch (1960: 4-5). An environmental image has three components: identity (the recognition of urban elements as separate entities), structure (the relation of urban elements to other objects and the observer), and meaning (its practical and emotional value to the observer). It is important that these urban elements are not hermetically designed into precise and final detail but present an open-ended order. Urban inhabitants should be able to form their own stories actively and create new activities in accordance with their experiences, traditions and cultural environments in which they have grown up.

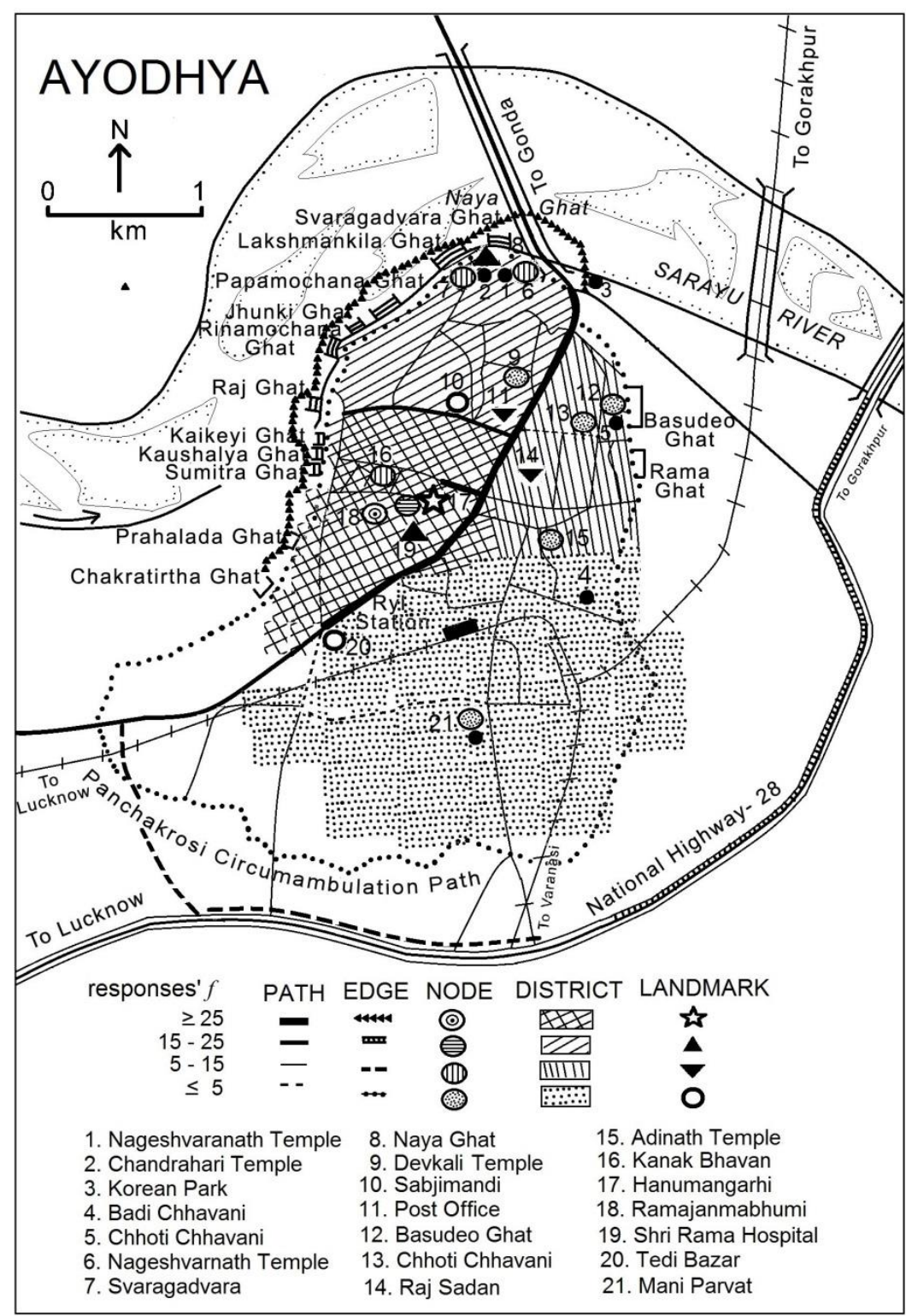

Figure 5- Ayodhya: Cognitive Map based on Perceptual Responses 
Table 8- The Frequency of Responses: Perception of the Five Basic Imageability Elements

\begin{tabular}{lccccccc} 
Se & $\begin{array}{l}\text { Frequency of } \\
\text { response* }\end{array}$ & Path & Landmark & Edge & Node & District & TOTAL \\
\hline 1 & $\geq 25$ & 2 & 1 & 1 & 1 & 1 & 6 \\
\hline 2 & $15-25$ & -- & 2 & 2 & 1 & 1 & 6 \\
\hline 3 & $5-15$ & 2 & 3 & 2 & 3 & 2 & 12 \\
\hline 4 & $\leq 5$ & 2 & 2 & -- & 5 & 2 & 11 \\
\hline-- & TOTAL & 6 & 8 & 5 & 10 & 6 & 35
\end{tabular}

Source: Collation of Data, please refer to Table 7

* category NA is also added, compare Figure 5

It is argued that "the cognitive map is a means to cope with societies complexities by bridging 'objective' and abstract representations of space, and subjective existential experiences of "lived space" (de Lange 2009). The composite cognitive map (also called as schemata, knowledge structure, mental map, and so on, Figure 5) clearly reveals that the very view of the Sarayu river seen from the north introduces not only what is best in the riverfront landscape but also registers a profound impression on the visitors' space preferences along with the northernmost limit (Edge) of the city. For tourists, boating is the main recreation along the ghats, while for the dwellers and pilgrims sacred bath and followed up rituals are more important.

The highest preference level among the Nodes is recorded at Ramajanmabhmi and Hanumangarhi temples (above $63 \%$ together), which together symbolises the vitality of the cultural personality of Ayodhya. The image of the Rama's temple further reflects its image in the form of a nickname, that is, the 'City of Lord Rama's birthplace'. Other important nodes refereed to are Kanak Bhavan and Nageshvaranath temple, recording 21 per cent frequency (see Table 8; Figure 5).

Among the Landmarks Hanumangarhi, Shri Ram Hospital and Naya Ghat together with recorded above 66 per cent. The Nodes and Landmarks

are surrounded by different types of Districts like residential areas, commercial areas, administrative and educational buildings, etc. Their common shape, size and the functional use provide a level of overall homogeneity in such areas. The familiarity level of Nodes is closely interlinked with the connecting Paths; indeed, they provide a way to cognise the city. The most popular channels of the movement are Ayodhya-Faizabad Road, and Hanumangarhi-Kanak Bhavan Rd, together with recorded around 78 per cent of responses (Table 8, Figure 5).

The edge is marked by the two life-incidences that refer to the lifeworld in Hindu tradition, that is, birth and death. Being the first rite purification is performed in the sacred water, in case of Ayodhya, it is the river Sarayu (in the source are called the Karnali, and in the plains as after meeting with the Sharada called the Ghaghara), the major tributary of the Ganga and conceived as her sister and has played a vital role in the development of the city and the religious act of purification as narrated in the historical past (e.g. Rig Veda, 4.30.18). According to mythology, Lord Rama was so closely attached to this river that in his final retreat from the earth he together with his close associate entered into the river (jalasamādhi). This has been a major scene in one of the major paintings of Mewar School (Figure 6). 


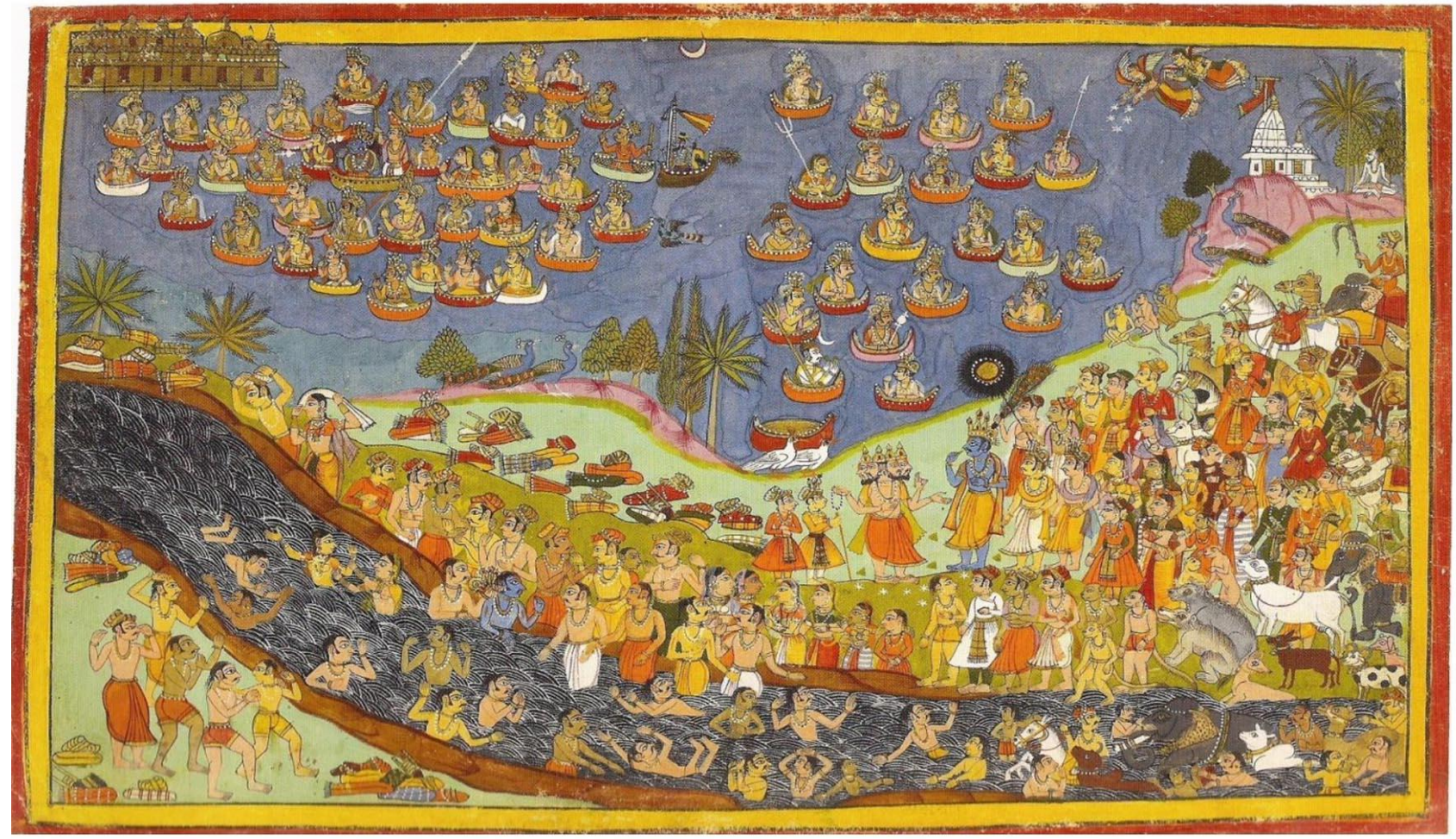

Figure 6- Lord Rama and Citizens of Ayodhya Entering the River Saryu as a Final Retreat from the Earth. Source: Mewar, CE 1649-54

\section{Concluding Remarks: Imageability vis-à-vis Legibility and Cognitive Map}

The growth of image from ancient to modern times, clearly indicates our present struggle, overrule and control for survival, and lack of confrontation and welcome to the strange (socalled). This reflects the gap in understanding and awareness. Tuan (1986: 19) has very timely warned us: "We also fear the strange for obvious reasons. It disturbs and disrupts; it resists our grasping ego; it frustrates our desire to place, classify, or to make consoling forms. There are no doubts, different modes of religious appreciation. One mode is this awareness of the strange not only "out there" but also in the midst of the "quotidian". This idea further emphasises the role of environmental, cultural awareness to preserving our cultural heritage while coping with the modern needs and value system.

In the purview of Tuan's views (1977), it is argued that human experience of the world (in all its fullness) both shapes and is shaped by space (existentiality) and place (experientiality). of course, Tuan develops this humanist argument against more abstract geographical conceptions of space. For him, the experience is both feelings and thought, in addition to the carrier of the cultural traditions, as exemplified in his illustration of China, but also compared with India too. Experience consists of all the myriad ways in which humans interact with their environment and learns the traditions in the passage of time: via the body (the five senses, along with "sensorimotor," moving through a space, and "body-touch"), via the imagination (including myths, fantasy, narration, memory, faith and belief systems, idiosyncrasy), and conceptually or rationally (a big-picture, correct or confused but conceived as confirmed).

It has been now accepted that "the human body is the first landscape we encounter and explore. It is likely that we carry the cognitive imagery in our heads as well as the actuality of our bodies as we approach the external environment. The landscape is our second major encounter" (Porteous 1986: 10). In the light of history, the imagery has been ever changing with the fact that man is becoming more individualistic (example, see, Figure 4). The bridge between the image and actuality 
can be made in the perspective of cultural landscapes vis-à-vis heritagescapes. On this line of thought, the Master Plan of the Greater Ayodhya-Faizabad region (2031) needs reorientation with an aim to preserve the cultural heritage and their aesthetic values that help to preserve the heritage and get it used in the inclusive city development.

\section{References}

Carmona, Matthew et al. (2010). Public PlacesUrban Spaces. The Dimensions of Urban Design. 2nd edition. Architectural PressTaylor \& Francis, Oxford.

de Lange, Michiel (2009, May 8). Review: Kevin Lynch - The Image of the City. The Mobile City.

http://themobilecity.nl/2009/05/08/revi ew-kevin-lynch-the-image-of-the-city/ <accessed: 18 Jan. 2018).

Denny, Fredrick M. (1991). Editor's Preface. In Meyer, Jeffrey E., The Dragons of Tiananmen: Beijing as Sacred City. University of South Carolina Press, Columbia, pp. ix-x.

Eisler, Anna D.; Eisler, Hannes and Yoshida, Mitsuo (2003). Perception of Human Ecology, Cross-cultural and Gender Comparisons. Journal of Environmental Psychology, 23 (1), March, pp. 89-101.

Gobster, Paul H.; Falmer, James F. and Crystal, Joseph (2003). Erwin H. Zube 19312002, The significance and impact of his contributions to Environment-Behavior Studies. Environment \& Behavior, 35 (2), March, pp. 165-186.

Golledge, Reginald G. (1987). Environmental cognition. In Stokols, Daniel and Altman, Irwin (eds.) Handbook of Environmental Psychology [2 vols.]. John Wiley \& Sons, New York, vol. I, pp. $131-174$.

Halperin, William C. (1988). Current topics in behavioural modelling of consumer choice; in, Reginald G. Golledge and Harry Timmermans, eds. Behavioural Modelling in Geography and Planning.
Croom Helm Ltd. Pub., London, pp. 126.

Kumar, Sarvesh and Singh, Rana P.B. (2013). Waterfront Cultural Landscape of Ayodhya (India), an Ancient Sacred Abode of Gods. South Asian Affairs (ISSN 1349-8851; Gifu Women's University, Gifu, Japan), 9, pp. 6-17.

Kumar, Sarvesh and Singh, Rana P.B. (2017). Ayodhya (India): a study of Ritual Landscapes. Practicing Geographer (ISSN: 0975-3850; Foundation of Practicing Geographers, Kolkata), 21 (2), Winter, pp. 71-84.

Lynch, Kevin (1960). The Image of the City. MIT Press, Cambridge, MA.

Lynch, Kevin (1976). 'Foreword'. In Moore, Gary T. and Golledge, Reginald G. (eds.) Environmental Knowing. Dowden, Hutchinson \& Ross, Stroudsburg, PA, pp. v - viii.

Lynch, Kevin (1984). Reconsidering the Image of the City. In Rodwin, Llyod and Hollister, Robert M. (eds.) Cities of the Mind. Plenum Press, New York, pp. 151 - 161

Porteous, J. Douglas (1996). Bodyscape: the Body-landscape metaphor. Canadian Geographer, 30 (1), pp. 2-12.

Rana, Pravin S. and Singh, Rana P.B. (2011). Perceptions and Images of Tourists and Pilgrims in Banaras. In Singh, Rana P.B. (ed.) Holy Places and Pilgrimages: Essays on India. Planet Earth \& Cultural Understanding Series, Pub. 8. Shubhi Publications, New Delhi, pp 165-206.

Rapoport, Amos (1990). The Meaning of Built Environment. University of Arizona Press, Tucson.

Rodwin, Lloyd and Hollister, Robert M., eds. (1984). Cities of the Mind. Images and Themes of the City in the Social Sciences. Plenum Press, New York.

Singh R.L. and Singh, Rana (1980). Urban landscape of Varanasi, a cultural synthesis. National Geographical 
Journal of India (N.G.S.I., Varanasi), 26 (3-4), pp. 113-123.

Singh, Rana P.B. (1988). The Image of Varanasi: Sacrality and Perceptual World. National Geographical Journal of India, 34 (1) March, pp. 01-32.

Singh, Rana P.B. (1994). Sacred Geometry of India's Holy City, Varanasi: Kashi as Cosmogram. National Geographical Journal of India, 40, pp. 189-216.

Singh, Rana P.B. (2002). Towards the Pilgrimage Archetype. Panchakrosi Yatra of Banaras. Pilgrimage \& Cosmology Series: 3. Indica Books, Varanasi.

Singh, Rana P.B. (2009). Cosmic Order and Cultural Astronomy: Sacred Cities of India. Planet Earth \& Cultural Understanding: Series Pub. 4. Cambridge Scholars Publishing, Newcastle upon Tyne. U.K.

Singh, Rana P.B. and Shahi, R.P. (1988). The Image of the City: Case of Deoria Town, India. National Geographical Journal of India, 34 (3), pp. 187 - 206.
Singh, Rana P. B. and Dubey, D.P. (1988). Mathura Mandala: Territory and Sacrality. In T.P. Verma, et al. (eds.) Yuga-Yugina Braj (A History of Braj Region). B. I. S. S., Varanasi, Pub. 6, pp. 189-200.

Tolman, E.C. (1932). Purposive Behavior in Animals and Men. Appleton-CenturyCrofts, New York.

Trowbridge, C.C. (1913). On fundamental methods of orientation and imaginary maps. Science, 36 (no. 90), Dec. 9, pp. $888-897$.

Tuan, Yi-Fu (1977). Space and Place. The Perspective of Experience. University of Minnesota Press, Minneapolis.

Tuan, Yi-Fu (1986). Stranger and strangeness. Geographical Review, 76 (1), pp. 10-19.

\section{Acknowledgements}

The authors are thankful to anonymous reviewers and editors for their critical reading and editing. 